\title{
The effectiveness of mood regulation skills training on the anxiety and irritability of students with disruptive mood disregulation disorder
}

\author{
Akram Nezami $^{1}$, Mohammad Ghamari ${ }^{2}$ \\ 1-M.A, Department of Psychology, Abhar Branch, Islamic Azad University, Abhar, Iran (Corresponding Author). \\ E-mail: akram.nezami65@yahoo.com \\ 2- Associate Professor, Department of Psychology, Abhar Branch, Islamic Azad University, Abhar, Iran.
}

Received: 03/03/2020

Accepted: 15/04/2020

\begin{abstract}
Introduction: Disruptive mood dysregulation that is characterized by chronic disorder is considered a new diagnosis in the fifth edition of the diagnostic and statistical manual of mental disorders (DSM-5) that is characterized by chronic, persistent and severe irritability in children and adolescents.

Aim: The aim of this study was to determine the effectiveness of mood regulation skills training in reducing anxiety and irritability of students with disruptive mood disregulation disorder.

Method: The method of research was a quasi-experimental with a pretest posttest and a control group. The research population included all male students of the first secondary school in Abhar city in the 2019-2020 academic year. Purposeful sampling was used to select 30 students who were randomly assigned as an experimental and a control group. The instruments of research were stringers emotional response index and beck anxiety questionnaire. The experimental group participated in mood regulation skills training sessions while the control group did not receive any interventions. To analyze the collected data in the pretest and posttest multivariate analysis of covariance (Mancova) with spss 21 was used.

Results: The findings showed that there was a significant difference between the mean scores of pretest and posttest in the experimental and control groups $(\mathrm{p}<0.01)$.

Conclusion: Mood regulation skills training reduces the irritability and anxiety of students with disruptive mood disorders.
\end{abstract}

Keywords: Mood regulation skills, Disruptive Mood Dysregulation Disorder, Irritability, Anxiety

How to cite this article : Nezami A, Ghamari M. The effectiveness of mood regulation skills training on the anxiety and irritability of students with disruptive mood disregulation disorder. Shenakht Journal of Psychology and Psychiatry. 2020; 7 (2): 116-127 .URL: http://shenakht.muk.ac.ir/article-1-755-fa.pdf 


\title{
اثربخشى آموزش مهارتهاى تنظيم خلق بر اضطراب و تحريكيذيرى دانش آموزان مبتلا به اختلال بد تنظيمى خلق اخلالكر
}

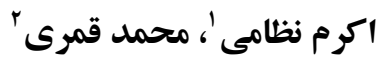 \\ ا. كارشناسى ارشد، كروه روانشناسى، واحد ابهر، دانشكاه آزاداسلامى، ابهر، ايران (مولف مسئول). ايميل: yahoo.com

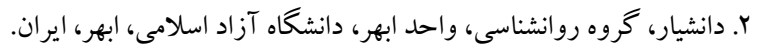 \\ تاريخ بذيرش مقاله: |ra9/P/TV \\ تاريخ دريافت مقاله: با/T/TraM|
}

جكيده

مقدمه: اختلال بد تنظيمى خلق اخلالكر، تشخيصى جديد در بنجمين ويرايش راهنماى تشخيصى و آمارى اختلالات روانى محسوب

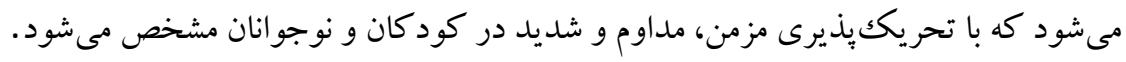
هدف: هدف يُزوهش حاضر تعيين اثربخشى آموزشهاى مهارتهاى تنظيم خلق در كاهش اضطراب و تحريككيذيرى دانش آموزان مبتلا به اختلال بد تنظيمى خلق اخلالخر بود.

روش: يُوهش حاضر از نوع نيمه آزمايشى با طرح بيش آزمون- بِ آزمون و گرووه كنترل بود. جامعه آمارى شامل تمامى

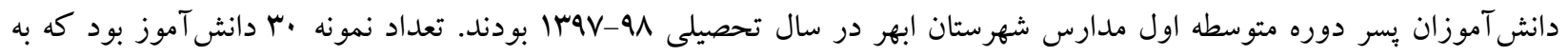
روش نمونه گيرى هدفمند انتخاب و به صورت تصادفى در دو گروه آزمايش و كنترل جايخزين شدند. ابزارهاى مورد استفاده شاخص

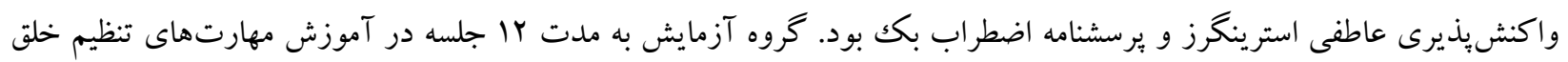

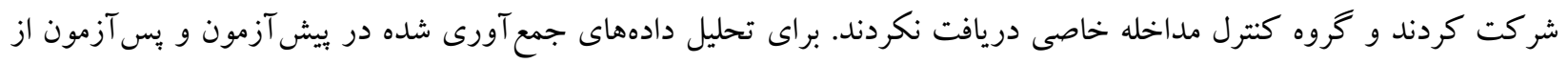

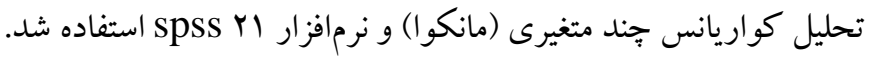

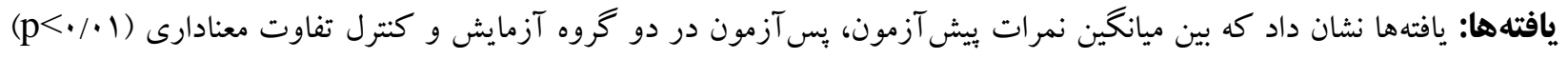
وجود دارد. نتيجه كيرى: آموزش تنظيم خلق باعث كاهش تحريكهيذيرى و اضطراب دانش آموزان مبتلا به اختلال بد تنظيمى خلق اخلالكر مى شود. كليد وازهها: مهارت تنظيم خلق، بد تنظيمى خلق اخلالكر، تحريككيذيرى، اضطراب 
(انجمن روانيزشكى آمريكا، سا.YY). بتن كورت، تالى،

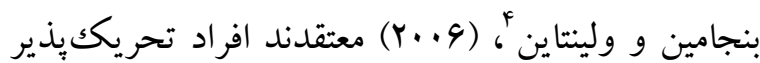
براى عصبانى شدن مستعدترند و حتى كوخك ترين تحريكك را به عنوان خطر و مشكل تلقى مى كنند. شواهد و تحقيقات كذشته نشان مىدهد هيج درمان خاصى براى اختلال خلق اخلالكر يا نا تنظيمى خلق شديد در حال

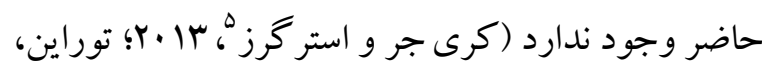
ليبيوف، بريتون، كوهن، در گيجنس، لابل و اتاك، ها (Y). در مطالعهاى كه بر روى بجّه هايى كه فنوتيب نزديك به به اختلال نا تنظيمى خلق شديد داشتند، يافتند كه ديوا ليروكس سديم در تركيب با رفتاردرمانى مؤثرتر از يّاسيبو به اضافه محرك در تركيب با رفتار درمانى است.

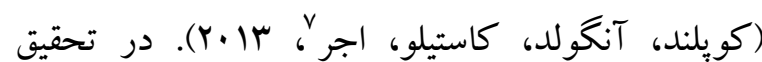
ديخر كه بر روى گرايش به قضاوت در مورد حالات مبهم صورت، در جوانان داراى اختلال بد تنظيمى خلق

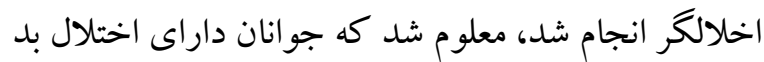

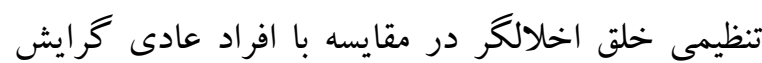
بيشترى به تفسير جهره مبهم، به جهرههاى عصبانى داشتند تا جهرههاى خوشحال. نتايج تحقيق همجِنين نشان داد كه در هر دو گرووه جوانان سالم و داراى اختلال بد تنظيمى

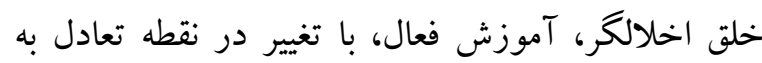
سمت قضاوت خوشحالتر همراه است. و شواهد نشان مىدهد كه آموزش فعال ممكن است با كاهش تحريك بذيرى و تغيير در فعاليت كرتكس مدار بيشانى جانبى همر اه باشد (استودرت، شريف عسكرى، هر كينز،

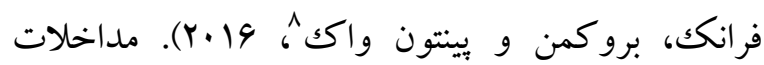
درمانى بايد بهطور ويثه بر راهبردهاى تنظيم هيجان

${ }^{4}$ - Bettencourt, Talley, Benjamin, Valentine،

5 - Krieger, Stringaris

${ }^{6}$ - Tourian, LeBoeuf, Breton, Cohen, Gignac, Labelle

7 - Copeland, Angold, Costello, Egge

${ }^{8}$ - Stoddard, Sharif-Askary, Harkins, Frank, Brotman, Penton-Voak اختلال بد تنظيمى خلق اخلالكر توسط كار گروههاى اختلالات خلق و اختلالات كودكى براى كودكان با مشكلات رفتارى و هيجانى شديد ارائه گرديد و تشخيص

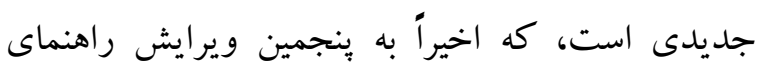
تشخيصى و آمارى اختلالات روانى به منظور سنجش

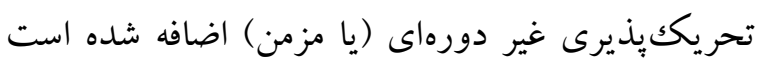

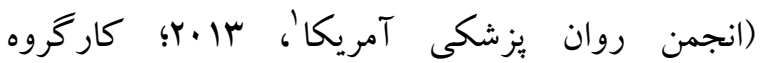

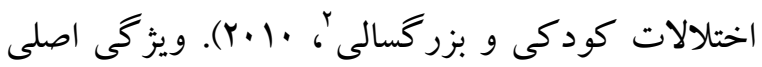
اختلال بد تنظيمى خلق اخلالخر، وجود تحريككيذيرى برى برى مزمن، مداوم و شديد است. تحريكِيذيرى به عنوان

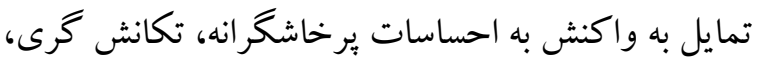
خصومت طلبى و رفتارهاى ناكامى در عدم توافق تعريف

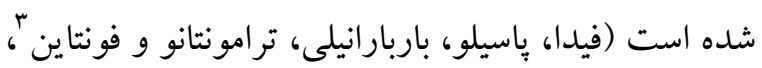

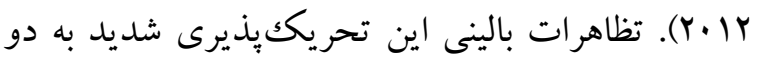
صورت مشاهده مىشود نخست: فورانهاى خشم مكرر كه عمدتاً در واكنشى به ناكامى به صورت كلامى و

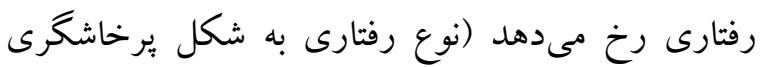
شديد نسبت به ديخران، خود يا اثاثيه). اين عصبانيت ها به له دفعات زياد (به طور متوسط حداقل هفتهاى سه بار) در طى حداقل يكك سال و حداقل در دو موقعيت متفاوت مانند خانه يا مدرسه رخ مىدهند و با سن رشدى فرد متناسب نيست. شكل دوم تظاهر تحريككيذيرى شديد، خلق عصبانى يا تحريككيذير مداوم و مزمنى است كه در بين فوران هاى خشم آنى ديده مىشود. اين خلق عصبانى يا تحريككيذير بايد از صفات شخصيتى كودك نشئت

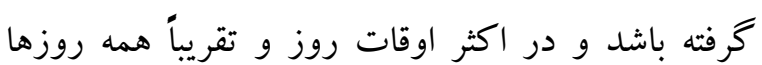
ديده شود و از نظر اطرافيان كودكك جشمخير باشد

\footnotetext{
1- American Psychiatric Association

2 - Bipolar disorder

3. Fida, Paciello, Barbaranelli, Tramontano \& Fontaine
} 
زيادى دارد جون وقتى خلقمان تنظيم نباشد، جه بيش از حد معمول بالا باشد و جه بيش از حد معمول بايين باشد مشكلاتى در زندگى و كاركردهايمان ايجاد مىشود و براى جلو گيرى از اين مشكلات بايد مهارت تنظيم خلق و و مقابله با خلق منفى را ياد بخيريم. در مورد نتايج درمانهاى روانشناختى در اختلال بد تنظيمى خلق

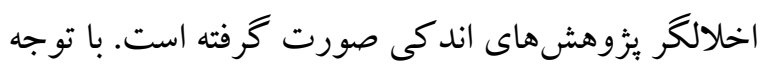
به اهميت و ضرورت اين يزوهش فرض مىشود كه آموزش مهارتهاى تنظيم خلق بتواند نقش مؤثرى در كاهش اضطراب و تحريكيذيرى افراد مبتلا به اين

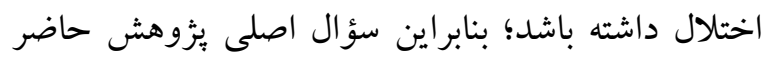
اين است كه آيا آموزش مهارتهاى تنظيم خلق در كاهش اضطراب و تحريك بذيرى دانش آموزان مبتلا به آنه اختلال بد تنظيمى خلق اخلالكر تأثير دارد؟

روش روش اين يُزوهش نيمه آزمايشى از نوع ييش آزمون و و

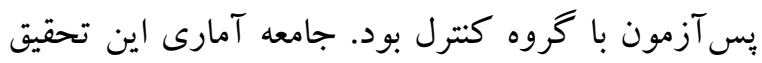

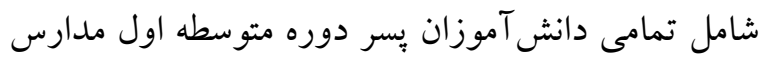

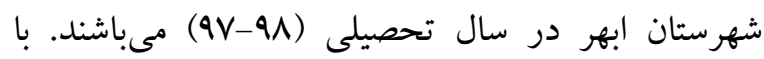
استفاده از روش نمونه گيرى هدفمند، ابتدا براى انتخاب

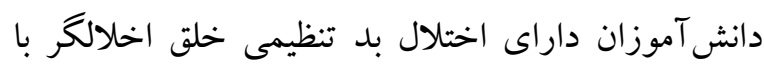
اخذ مجوز از آموزش ويرورش و با مراجعه به مدارس

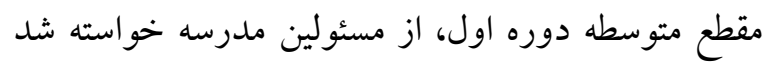
كه دانش آموزانى كه مشكل انضباطى در مدرسه دارند را

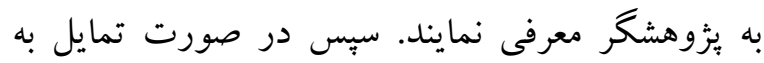

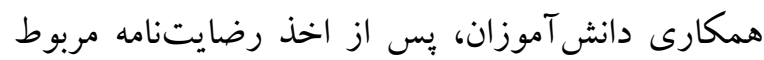
به والدين، از همه آنهايى كه معرفى شده بودند (ب... نفر)، بهوسيله شاخص واكنشيذيرى عاطفى و ير سشنامه
تمركز كنند ؛زيرا جنين مداخلاتى ممكن است اثرات

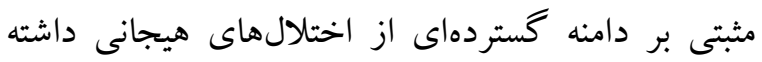

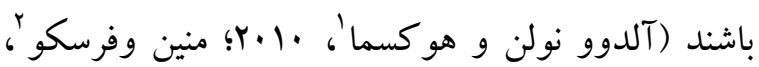

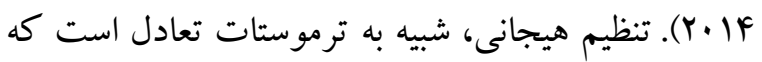

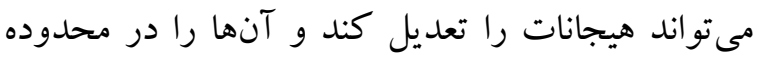
كنترل نيخه دارد؛ بهطورى كه شخص بتواند بات با آنها كنار

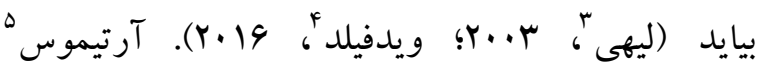
وهمكاران (r.Y.T) در بززوهش خود با عنوان اثربخشى آموزش مهارتهاى مقابله با خلق منفى و كاهش اضطراب و استرس و بهبود كيفيت زندگى دانشجويان يرستارى به اين نتيجه دست يافتند كه آموزش مهارتهاى مقابله با خلق منفى بر كاهش اضطراب و لئه استرس و بهبود كيفيت زندگى دانشجويان برستارى تأثير باتير

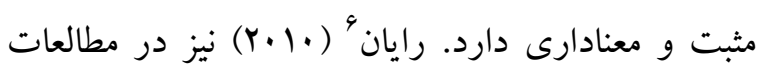
خود با عنوان اثربخشى آموزش مهارتهاى مقابله با خلق منفى بركاهش اضطراب و استرس و بهبود عملكرد دانش آموزان به اين نتيجه رسيد كه آموزش مهارتهاى مقابله با خلق منفى بر كاهش اضطراب و استرس و وبهبود

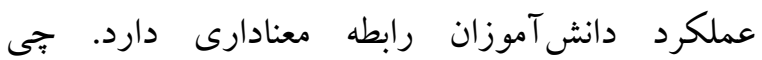

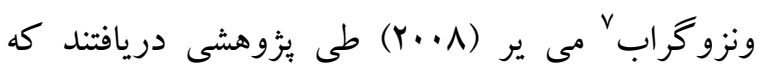
آموزش مهارتهاى مقابله با خلق منفى بر كاهش اضطراب و استرس و خودكترلى دانش آموزان مؤثر

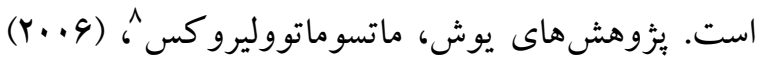
نيز حاكى از اين است كه تنظيم هيجان، سازكارى مثبت

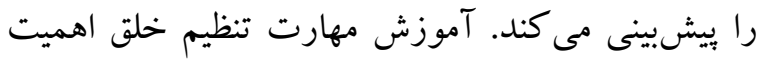

\footnotetext{
1. Aldao, Nolen-Hoeksema, Schweizer

- Mennin \& Fresco

3- Lihy

4. Vidfilt

5- Artimos

6- Rayun

7. Chvenzgrab

8. Yoo SH, Matsumoto D, LeRoux JA
} 
مهارتهاى تنظيم خلق به مدت rا جلسه (·9 دقيقهاى) به صورت گروهى و هفتهاى يكك بار در مركز مشاوره آموزش داده شد و بس از دوره آموزشى از هر دو گروه (آزمايش و كنترل) يس آزمون كرفته شد. جلسات آموزشى مهارتهاى تنظيم خلق: اين جلسات بر خرفته از منابع مرتبط و با بشتوانهى بثزوهشى در زمينهى

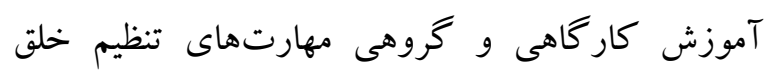

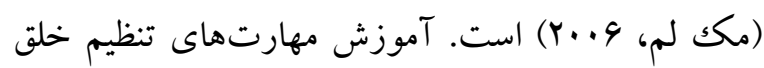
به دليل تأكيد بر فرايندهاى هيجانى دانش آموزان داراى خلق اخلالخر تلاش براى تأثير كذاشتن روى نوع، زمان و

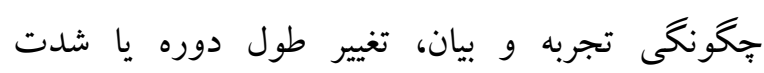
فرايندهاى رفتارى، تجربى و يا جسمانى هيجانها است و

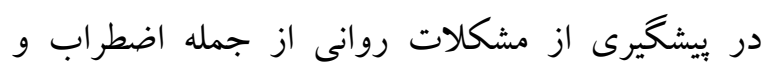
استرس و تحريككيذيرى نقش مؤثرى دارد. با توجه به اين كه آموزش تنظيم خلق درمان قابل قبولى براى كاهش اضطراب و آشفتخى هيجانى و تحريك يذيرى دانشآموزان مبتلا به اختلال بد تنظيمى خلق اخلالكر است؛ بنابراين مىتوان از اين آموزش در درمان اين اختلال جديد بهره برد. خلاصه جلسات به اين ترتيب
اضطراب بك كه توسط والدين آنها در مورد فرزندانشان تكميل شد، غربالگرى و آنان كه در اين برسشنامه نمره برش r را در گزارش والدين داشتهاند

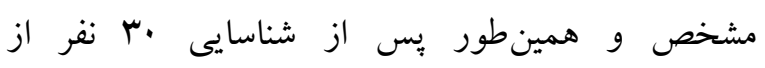
دانش آموزانى كه نمرات آنها در اين برسشنامها بالاتر از يكك انحراف معيار از ميانگين بود و پِ بس از مصاحبه

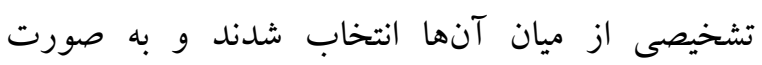
تصادفى در دو گروه (ها نفر آزمايش) و (ها نفر كنترل)

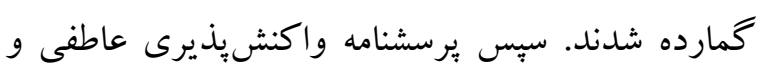
برسشنامه اضطراب بكك، در اختيار آنها قرار كرفت. ملاككهاى ورود به يزٔوهش عبارت بودند از دانش آموزان

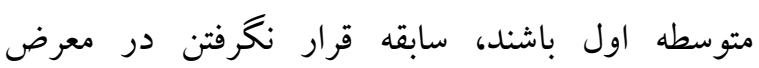
آموزشهاى روانشناختى، بر كردن فرم همكارى و رضايتمندى جهت شركت در جلسات درمانى و ملاككهاى خروج نيز شامل عدم همكارى گروه نمونه يا

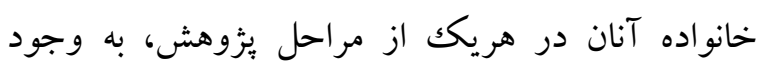
آمدن مشكلات تحصيلى در طى آزمايش و تداخل درمانى در صورتى كه اعضاى گروه نيازمند درمان جسمى و روانشناختى باشند. قبل از اعمال متغيرهاى

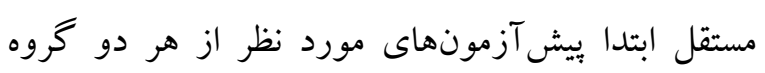

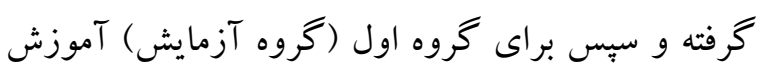

\begin{tabular}{|c|c|}
\hline 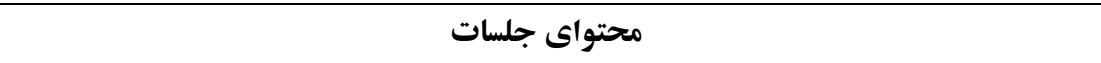 & جلسه \\
\hline توجيه دانش آموزان و آشنايى با مفهوم هيجان و خلق منفى و تنظيم خلق & 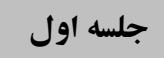 \\
\hline خام گذارى احساسات، بى نظمى هيجانات، رابطهى اختلالات و تنظيم خلق منفى، علائم فيزيولوزيكك و روانى، & 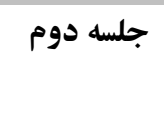 \\
\hline تعريف استرس و اضطراب و زشانهاى آن، مشكلات ناشى از ناتوانى در مديريت استرس & 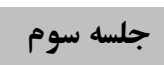 \\
\hline آموزش تنظيم هيجانات مثبت و منفى و واكنشهاى ساز كارانه و ناساز كارانه به اضطراب & 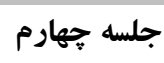 \\
\hline آموزش راهبردهاى مقابلهاى با اضطراب & 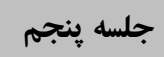 \\
\hline
\end{tabular}


جلسه ششم تعريف خشم و نشانهاى آن، مشكلات ناشى از ناتوانى در مديريت خشم و كنترل تكانه، شناسايى و

خوديايى خشم

آموزش راهبردهاى مقابلهاى باخشم، سبكهاى رفتارى مناسب يذيرش رويدادها و هيجانات منفى،

اصلاحات هيجانات منفى

شناسايى غمخينى، ناميدى و احساس شكست و ديخر احساسات و راهبردهاى مقابلهاى

جلسه هفتم

جلسه نهم آموزش خود كنترلى رفتار و تنظيم هيجانات و جرأت ورزى در ابراز هيجانها

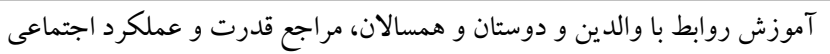

جلسه دهم

آموزش قواعد ابراز، همدلى، ساز گارى و انعطاف يذيرى

جلسه يازدهم

جلسه دوازدهم تعميم آموختها

درست و r = مطمئناً درست و مجموع اين سؤالات نمره فرد را تشكيل مىدهد كه از دامنه · تا r ا است. همجينين در آزمون در يكك سؤال مجزا از فرد يا والدينش برسيده مىشود "روىهمرفته تحريككيذيرى باعث مشكلاتى در

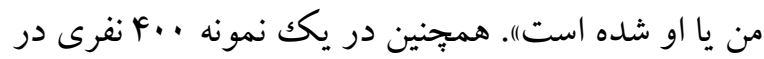
شهر مشهد ضريب آلفاى كرونباخ •V/ · را كزارش شده است كه معنىدار است. ضريب پايايى يرسشنامه حاضر

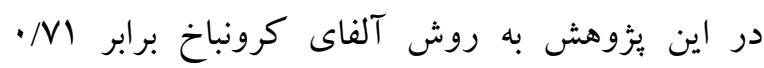
محاسبه شد. يرسشنامه اضطراب بك (BAI): يرسشنامه اضطر اب بك إك توسط آرون تى بكك و همكارانش ' در سال $19 M 1$ ساخته شد. اين برسشنامه يكك برسشنامه خود گزارشى است كه

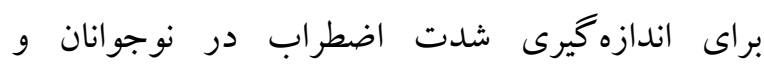
بزر گسالان تهيه شده است به طور اختصاصى شدت علائم اضطراب بالينى رادر افراد مىسنجد .اين برسشنامه يكك مقياس الY مادهاى است و هر يكك از مادههاى آن يكى از علائم شايع اضطراب يعنى علائم ذهنى، علائم بدنى و هراس را مىسنجد؛ كه گزينه ا صفر نمره، گزينه

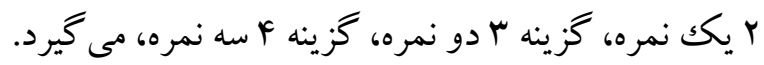

\footnotetext{
1. Beck AT, Epstein N, Brown G, Steer RA
}

براى تحليل دادههاى جمع آورى شده در يِش آزمون و بس آزمون از تحليل كواريانس جند متغيرى (مانكوا) و نرم افزار التو استفاده شد.

\section{ابزار} شاخص واكنشيذيرى عاطفى استريكرز: اين مقياس

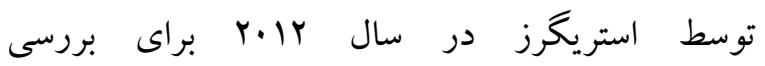
تحريككيذيرى در كودكان و نوجوانان ساخته شد.

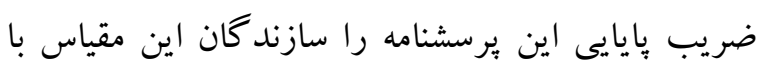
استفاده از محاسبه آلفاى كرونباخ در نمونه آمريكايى

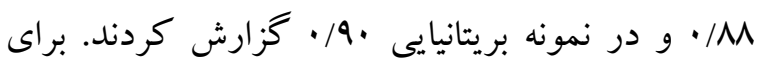
سنجش روايى اين مقياس، از جند روش روايى شامل روايى محتوا، همخرا و سازه استفاده شد. محققان اين آزمون را به دو شيوه خود كزارشى و سؤال از والدين آنها ساختند. والدين بايد به اين 9 سؤال بر اساس اينكه "ادر 4 ماهه كذشته در مقايسه با ساير كودكان هم سن،

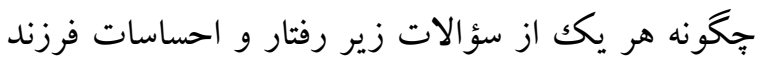
شما را توصيف مى كند؟)، ياسخ مىدادند. در نسخه خود كزارشى از بجهها و نوجوانان مى خواستند كه به جملات حاوى توصيف رفتارشان پاسخ دهند. اين پاسخها در يكك طيف سه درجهاى بود كه · = نادرست، ا= =ا حدى حسى 
شده نشان مىدهد كه اين برسشنامه از اعتبار و روايى

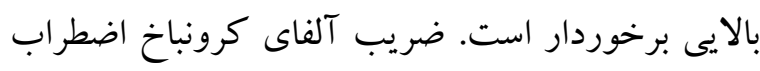

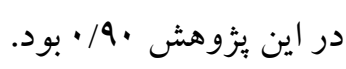

يافتهها تعداد كل نمونهها ·r نفر از دانش آموزان پِّر داراى اختلال خلق اخلالكر بودند كه در دو گروه آزمايش و

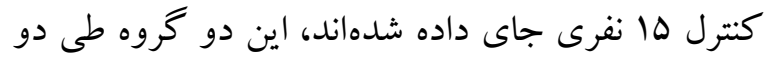

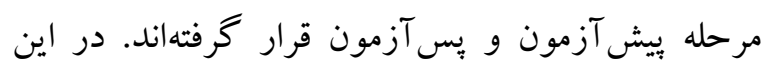
بخش به توصيف آمارى متغيرها مى يردازيم. جدول

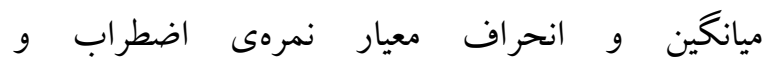
تحريك بذيرى در گروههاى آزمايش و كنترل به تفكيك در مراحل بيش آزمون و پِ آزمون را نشان مىدهد.
نمره كل در دامنهاى از · تا سو قرار مى گيرد، در صورتى

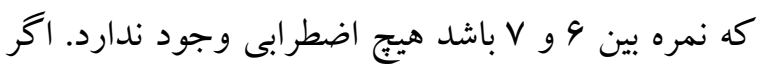

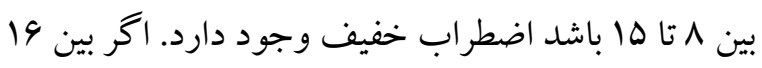

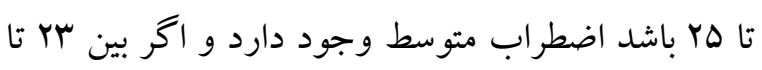

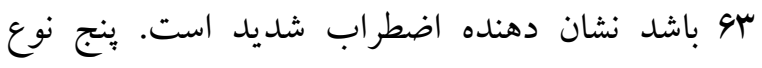
روايى محتوا، همزمان، سازه، تشخيصى و عاملى براى اين

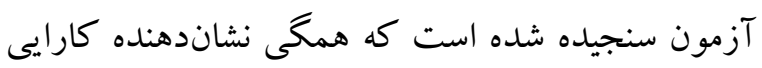
بالاى اين ابزار در اندازگيرى شدت اضطراب است

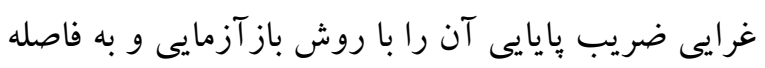
دو هفته •1 /• كزارش كرده است. كاويانى و موسوى

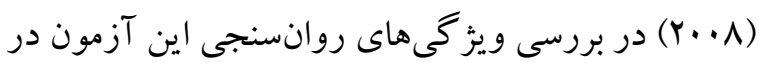

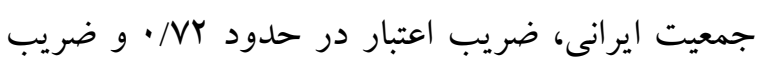

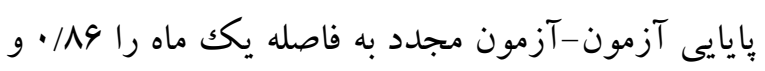

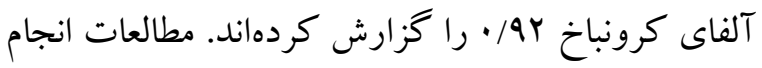

\begin{tabular}{|c|c|c|c|c|}
\hline يس آزمون & يِيش آزمون & ميانكين وانحر اف معيار & كروه & متغير \\
\hline $11 / 9 r$ & $r \cdot 19$. & ميانگين & \multirow[t]{2}{*}{ كروه آزمايش } & \multirow[t]{4}{*}{ اضطراب } \\
\hline$\Delta / v \Delta$ & $V / N I$ & انحر اف معيار & & \\
\hline$r \cdot / 9 r$ & $r I / r$. & ميانگين & \multirow[t]{2}{*}{ گروه كنترل } & \\
\hline$r / T F$ & $r / v q$ & انحر اف معيار & & \\
\hline$\Delta / .9$ & १/१५ & ميانگين & \multirow[t]{2}{*}{ گروه آزمايش } & \multirow[t]{4}{*}{ نحر يك يذيرى } \\
\hline $1 / 19$ & $1 / T V$ & انحر اف معيار & & \\
\hline N/qr & $9 / 4$ & ميانكين & \multirow[t]{2}{*}{ كروه كنترل } & \\
\hline $1 / \cdot r$ & $1 / F \Delta$ & انحر اف معيار & & \\
\hline
\end{tabular}

تحريككيذيرى نسبت به بيشآزمون كاهش نشان

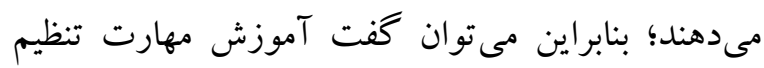

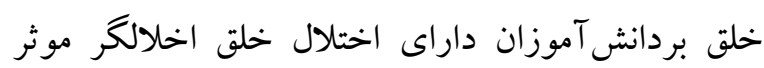
است وتفاوت معنىدارى دارد. در جدول بـ اطلاعات
در جدول Y براساس نتايج به دست آمده در بيش آزمون،

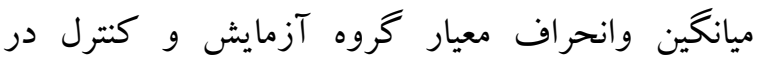

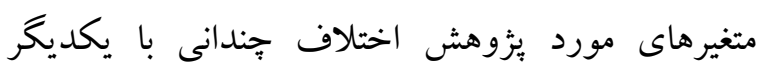
ندارند؛ اما در گروه آزمايش در مرحله پِّ آزمون

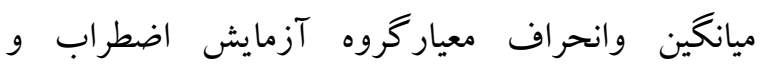


مربوط به شاخصهاى اعتبارى آزمون تحليل كواريانس جند متغيرى را با كنترل بيش آزمونها را نشان مىدهد.

\begin{tabular}{|c|c|c|c|c|c|c|}
\hline سطح معنى & اندازه ى اثر & آزادى خطا & درجه آزادى & Fقدار F & مقدار & نام آزمون \\
\hline$\cdot / \cdot 1$ & $\cdot 19 \cdot r$ & ro & r & $10 / 1 Y$ & $\cdot 19 \cdot Y$ & اثرييلاى \\
\hline$\cdot / \cdot .1$ & $\cdot 19 \cdot Y$ & ro & $r$ & $10 / 1 T$ & • Mar & لامبداى ويلكز \\
\hline$\cdot / \cdot 1$ & $\cdot 19 \cdot Y$ & ro & r & $10 / 1 Y$ & $1 / 4 \pi$ & اثرهتلينك \\
\hline.$/ \cdot 1$ & $\cdot 19 \cdot Y$ & ro & r & $10 / 1 T$ & $1 / 4 \pi$ & بزر رتترين ريشه \\
\hline
\end{tabular}

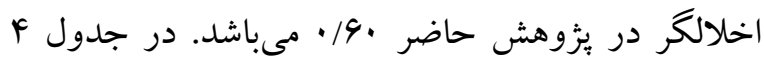
براى استفاده از تحليل كواريانس از آزمون همخنى واريانس و همكنى شيب رگرسيون و نرمال بودن توزيع دادهها به عنوان بيش فرض استفاده مىشود.
مندرجات جدول ب نشان مىدهد كه بين گروه آزمايش و كنترل در بِ آزمون از لحاظ متغيرهاى وابسته در سطح ت باوت معنىدارى وجود دارد بنابر اين فرضيه تحقيق يثوهش حاضر تأييد گرديد. اندازهى اثربخشى آموزش مهارت تنظيم خلق بر دانشآموزان داراى خلق

\begin{tabular}{|c|c|c|c|c|c|c|}
\hline \multicolumn{2}{|c|}{ نرمال بودن توزيع داده ها } & \multicolumn{2}{|c|}{ همكنى شيب ركرسيون } & \multicolumn{3}{|c|}{ همغنى واريانس } \\
\hline سطح معنادارى & درجه تاثير & سطح معنادارى & و اريانس & سطح معنادارى & لويين & متغيير \\
\hline$\cdot / \Delta 1$ & .19. & .111 & r/GY & $\cdot / A F$ &.$/ r$ & اضطر اب \\
\hline.$/ 9 V$ & $\cdot / 4 \wedge$ & $\cdot / 4 \Lambda$ & $\cdot / \Delta$ & $\cdot / 4 T$ & .194 & تحر يك يذيرى \\
\hline
\end{tabular}

متن مانكوا انجام گرفت. جدول ه تحليل كوواريانس

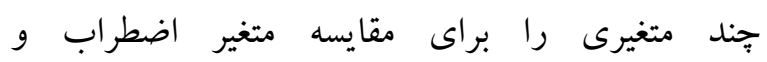
تحريك يذيرى در گروههاى آزمايش و كنترل با كنترل نمر ات بيش آزمون را نشان مىدهد.
جدول F نشان داد ييش فرضهاى همخنى واريانس و همخنى شيب رگرسيون و نرمال بودن توزيع دادهها براى استفاده از تحليل كواريانس تاييد مى گردد. براى مشخص كردن نقطهى تفاوت دو تحليل كوواريانس يكراهه در

\begin{tabular}{|c|c|c|c|c|c|}
\hline معنادارى سطح & $\mathbf{F}$ & مجذوراتكين & درجه آزادى & مجذوروات & متغيير \\
\hline$\cdot / \cdot 1$ & IDY/AV & rqY/r. & 1 & FGY /r. & اضطر اب \\
\hline$\% \cdot \cdot 1$ & $V G / M \Lambda$ & $11 Y / \cdot r$ & 1 & $11 r / \cdot r$ & تحر يك يذيرى \\
\hline
\end{tabular}


(ويلوتى، كاروفالو، بتروجى، كاوالو، يويولو و ديماكيو؛

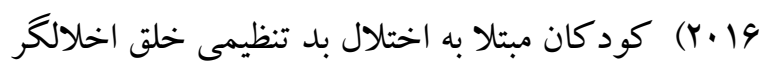
به علت خلق بالا، بىنظمى در رفتار، همجينين همبودى با بال ساير اختلالات و مشكلات طولانى مدت (از جمله درصد

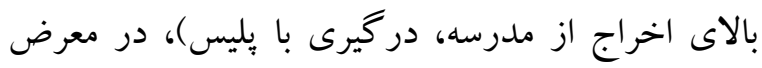
خطر بيشترى هستند (كويلند، شاناهان، اجر، آنخولد و و

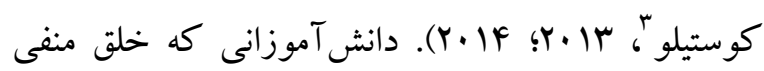
بايينى دارند در زمان رويارويى با هيجانات منفى، اين افراد دجار تنش، اضطراب و ترس مىشوند (توماس،

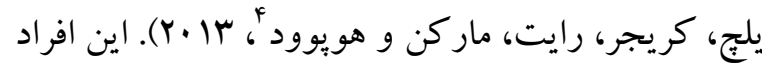
در فشـارهاى تحصسيلى و اسـترسهـا قادر نيستند موقعيت مناسب را ارزيابى كند و راهبردهايى مؤثر براى تغيير موقعيت يا تنظيم هاسخهاى هيجانى خود به كار

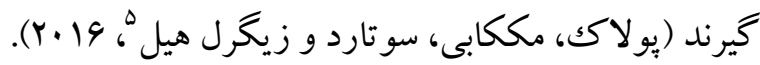

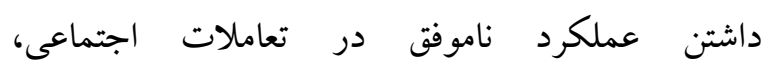

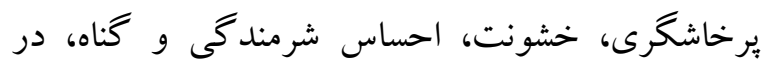

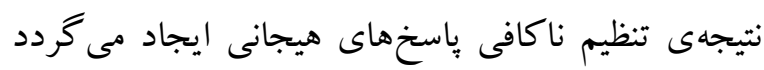

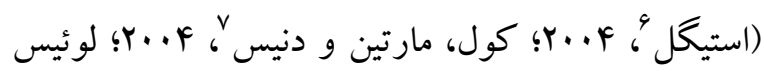

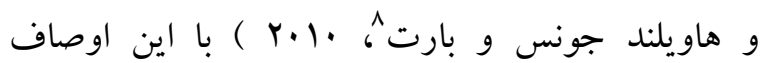
آموزش مهارت تنظيم خلق منفى شامل شناسايى و يذيرش افكار و احساسات منفى است زمينه را براى باز

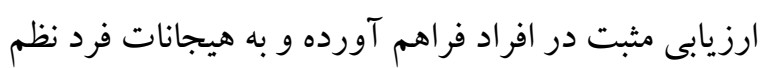

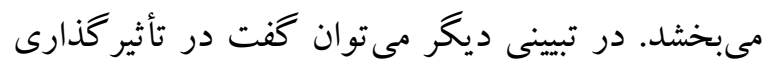
آموزش مهارت تنظيم خلق منفى بر دانش آموزان داراى خلق اخلالكر مىتوان به اين مسئله اشاره نمود كه در

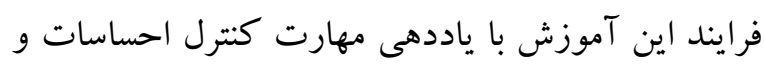

2. Velotti, Garofalo, Petrocchi, Cavallo, Popolo, \& Dimaggio

3 - Copeland WE, Angold A, Costello EJ, Egger

${ }^{4}$ - Thomas, Yalch, Krueger, Wright, Markon, Hopwood

5 - Pollock NC, McCabe GA, Southard AC, Zeigler-Hill V

${ }^{6}$ - Astigal

7- Cole, P. M, Martin, S. E. \& Dennis, T. A

${ }^{8}$ - Lewis, M. D., Haviland-Jones, J. M. \& Barrett,
در جدول ه نتايج تحليل كواريانس جند متغيرى نشان مىدهد كه تفاوت ميانخين گروه آزمايش و گروه كنترل در پِس آزمون در مؤلفهاى اضطراب و تحريك يذيدي تفاوت معنىدارى در سطح (F VG/r/ , Flor/AV) p< وجود دارد؛ بنابر اين يافتها نشان مىدهد كه آموزش مهارتهاى تنظيم خلق بر اضطراب و و آنابر تحريك يذيرى دانش آموزان مبتلا به خلق اخلالكر مؤثر بوده است. به عبارتى اين فرضيهى يُووهشى كه آموزش

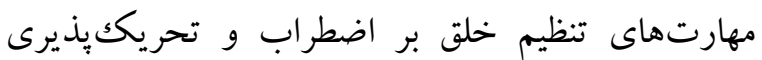
دانش آموزان بسر مبتلا به اختلال بد تنظيمى خلق اخلالكر بلتر

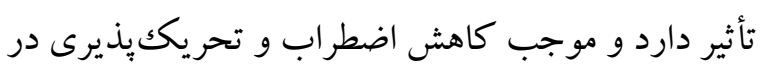
دانش آموزان شده تأييد مى دشود.

هدف از انجام اين يُزوهش اثربخشى آموزش مهارتهاى تنظيم خلق بر اضطراب و تحريك يذيرى دانش آموزان يسر مبتلا به اختلال بد تنظيمى خلق اخلالكر بود. تحليل كواريانس نشان داد كه آموزش مهارتهاى تنظيم خلق

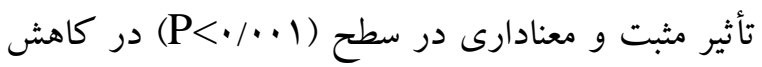
اضطراب و تحريككيذيرى دانش آموزان دارد؛ بنابراين

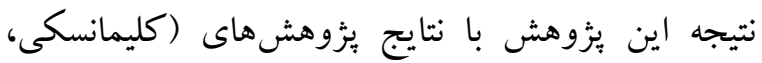

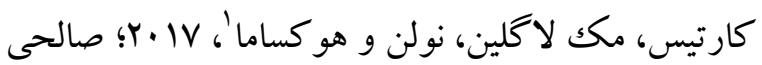
و همكاران، r|r.r) از لحاظ داشتن مشكلات تنظيم هيجان همسو است. يافتهها نشان مىدهد كه در افراد داراى خلق اخلالكر مشكلات هيجانى بسيارى وجود

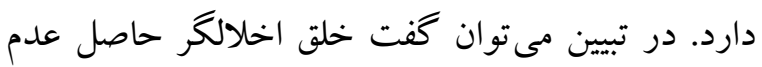
ابراز هيجانها به دليل نارسايى در تو انايى يردازش و نظم آنان دهى هيجانها و يا بازدارى آكاهانه ابراز آن است داست

\footnotetext{
1. Klemanski, Curtiss, McLaughlin, Nolen-Hoeksema
} 
افراد كمك شايانى نمود. از محدوديت عمده اين يزوهش در تعميم نتايج به ديكر گروهها است كه بايد جوانب احتياط را رعايت نمود. بيشنهاد مىشود از آنجا بان كه اين اختلال يكك اختلال جديد بوده و در ايران و حتى در دنيا بر روى شيوههاى مؤثر درمانى خيلى كار نشده است از درمان روانشناختى بذيرش و تعهد و ديخر درمانهاى مرتبط نيز استفاده شود، همجنين بيشنهاد مىشود تأثير اين درمان، بر خودكارآمدى تحصيلى اين دانش آموزان مورد بررسى بيشترى قرار گيرد. همجينين يشنهاد مى گردد سازمانهاى مربوطه جهت تربيت متخصصان و همجنين آموزش اين شيوه به مشاوران مدرسه اقدام نمايند.

\section{سياسگزارى}

بدين وسيله از كليه دانشآموزان و والدين آنها و همينطور از مديران مدارس كه نهايت همكارى با اين بثزوهش را داشتند تشكر و قدردانى به عمل مى آيد.

\section{References}

Aldao A, Nolen Hoeksema S, \& Schweizer S. (2010). Emotion-regulation strategies across psychotherapy: A meta-analytic review. Clinical Psychology Review, 30, 217-237.

American Psychiatric Association. (2013). Diagnostic and Statistical Manual of Mental Disorders Fifth Edition. Washington, DC: American Psychiatric Publishing.53(11):1019-18.

American Psychiatric Association. Taskforce DV. (2010). Issues pertinent to developmental approach to bipolar disorder in DSM-5 [Internet]. Washington, DC: American Psychiatric Association; 397.

Artemios A, Harrisons \& Jerald. (2012). Principles of intemational Medicine. American: New York \& sons: Ltd,50,219-240.
تمركز بر افكار مثبت بتواند احساس كنترل زيادى را در رابطه با تجارب منفى زندگى خود كسب نموده و هيجانات خود را مثبت و اميد بخش تفسير نمايند (قربانى، خسروانى، جماعتى، اردكانى، الوانى و اكبرى، IV) (Y). يكى از مواردى كه در جلسات آموزش مهارت تنظيم خلق منفى آموزش داده شد بذيرش رويدادها و هيجانات منفى، اصلاحات هيجانات منفى و جرأت ورزى در ابراز هيجانها است. لذا آموزش مهارتهاى تنظيم خلق به دليل تأكيد بر فرايندهاى هيجانى افراد مبتلا به خلق اخلالكر، مىتواند تحريككيذيرى و اضطراب اين افراد را

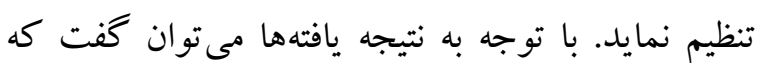

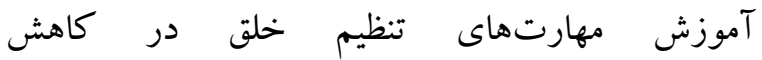

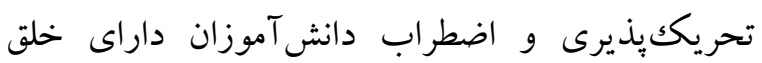

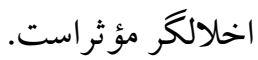

\section{نتيجه كيرى}

لذا با شناخت و آكاهى از اين فرايند إهاى هيجانى، مى توان با آموزش مهارتهاى تنظيم خلق سيستم هيجانى اين افراد را تنظيم كرد و از اضطراب و تحريككيذيرى

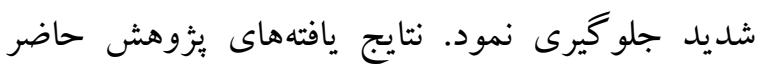
نشان مىدهد كه آموزش مهارتهاى تنظيم خلق منجر به كاهش مثبت و معنادارى در تحريك يذيرى و اضطراب

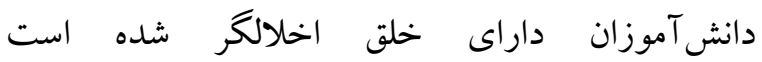
تجزيهوتحليل يافتها نيز دال بر اثربخشى اين آموزش است. لذا اين روش به عنوان يكك روش مؤثر و كاربردى لهري در كلينيكها و مراكز درمان روانشناختى، قابليت اجرايى اثربخش را دارد. همجنين در نتيجه استفاده از

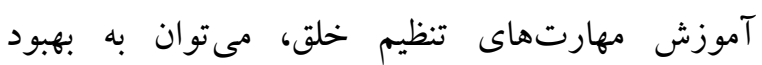
ويز كىهاى روانشناختى و اصلاح روابط اجتماعى اين 
Beck AT, Epstein N, Brown G, Steer RA. (1988). An inventory for measuring clinical anxiety: psychometric properties. J Consult Clin Psychol .56: 893-7.

Bettencourt BA, Talley A, Benjamin AJ, Valentine J. (2006). Personality and aggressive behavior under provoking and neutral conditions: a meta-analytic review. Psychol Bull. 132(5):751-77.

Bipolar disorder and disuptive mood dysregulation in children and adolescents. (2010). assessment, diagnosis and treatment. Evid Based Ment Health. 16(4):93-4.

Chivenzn M, \& Miyer G. (2008). Cognitive behavioral stress management improves stressmanagement skills and quality of life in men recovering from treatment of prostate carcinoma, Cancer, 100 (1), 192-00.

Cole PM, Martin SE, \& Dennis TA. (2004). Emotion Regulation as a Scientific Construct: Methodological Challenges and Directions for Child Development Research. Child Development, 75(2), 317-333.

Copeland WE, Angold A, Costello EJ, Egger H. (2013). Prevalence, comorbidity, and correlates of DSM-5 proposed disruptive mood dysregulation disorder. Am J Psychiatry. 170(2):173-9.

Copeland WE, Shanahan L, Egger H, Angold A, \& Costello EJ. (2014). Adult diagnostic and functional outcomes of DSM-5 disnuptive mood dysregulation disorder. The American Journal of Psychiatry, 171(6), 668-674.

DSM-5 Childhood and Adolescent Disorders Work Group. (2010). Justification for Temper Dysregulation Disorder with Dysphoria. Washington, DC: American Psychiatric Association.54(2),274-23.

Fida R, Paciello M, Barbaranelli C, Tramontano C, Fontaine RG. (2012). The role of irritability in the relation between job stressors, emotional reactivity, and counterproductive work behaviour. Eur J Work Organ Psychol. 23(1):31-47.

Ghorbani F, Khosravani V, Jamaati Ardakani R, Alvani A, \& Akbari H. (2017). The mediating effects of cognitive emotion regulation strategies on the relationship between alexithymia and physical symptoms: Evidence from Iranian asthmatic patients. Psychiatry Research, 247, 144-151.

Kaviani H, \& Mousavi AS. (2008). Psychometric properties of the Persian version of Beck Anxiety Inventory (BAI). Tehran University Medical Joumal. 65(2): 136-140. (Persian).

Klemanski DH, Curtiss J, McLaughlin KA, NolenHoeksema S. (2017). Emotion Regulation and the TransdiagnosticRole of Repetitive Negative Thinking in Adolescents with Social Anxiety and Depression. Cognit Ther Res. 41(2):206-19.

Krieger FV, Stringaris A. (2013). Bipolar disorder and disnuptive mood dysregulation in children and adolescents: assessment, diagnosis and treatment. Evid Based Ment Health. 16(4):934.

Leahy R. (2003). Cognitive Therapy Techniques: A Practitioner's Guide. New York: Guilford Press. 17(3):85-4.

Lewis MD, Haviland-Jones JM, \& Barrett LF. (2010). Handbook of Emotions (Third Edition). New York: The Guilford Press.168(2):140-30.

Macklem GL. (2006). Strengthening the effect of social skills training. Massachusetts School Psychologists Association New letter, 25(1), 12-46.

Mennin DS, \& Fresco DM. (2014). Emotion regulation therapy. In J. J. Gross (Ed.), Handbook of emotion regulation. New York: Guilford Press., pp 469-490.

Pollock NC, McCabe GA, Southard AC, Zeigler-Hill V. (2016). Pathological personality traits and emotion regulation difficulties. Pers Individ Dif 95:168-77.

Rayan. (2010). Coping and emotion in stress and coping. Ed by Monat \& R.S Lazarmuss. New York: Colombia University Press. 50 (3): 170 63.

Salehi A, Baghban I, Bahrami F, Ahmadi SA. (2012). The effect of emotion regulation training based on dialectical behavior therapy and gross process model on symptoms of emotional 
اثربخشى آموزش مهارتهاى تنظيم خلق بر اضطراب و تحريككيذيرى دانش آموزان مبتلا به اختلال بد تنظيمى خلق اخلالكر

problems. Zahedan J Res Med Sci.14(2):49-

55.

Stegall SD. (2004). Adolescent emotional development: Among shame and guilt proneness, emotion regulation, and psychopathology [dissertation]. Maine: University of Maine. 30(2):41-65.

Stoddard J, Sharif-Askary B, Harkins EA, Frank HR, Brotman MA, Penton-Voak IS, et al. (2016). An Open Pilot Study of Training Hostile Interpretation Bias to Treat Disruptive Mood Dysregulation Disorder. J Child Adolesc Psychopharmacol. 26(1):49-57.

Thomas KM, Yalch MM, Krueger RF, Wright AG, Markon KE, Hopwood CJ. (2013) The convergent structure of DSM-5 personality trait facets and fivefactor model trait domains. Assessment 20(3):308-11.

Tourian L, LeBoeuf A, Breton JJ, Cohen D, Gignac M, Labelle R, et al. (2015). Treatment Options for the Cardinal Symptoms of Disnuptive Mood Dysregulation Disorder. J Can Acad Child Adolesc Psychiatry. 24(1):41-54.

Velotti P, GarofaloC, Petrocchi C, CavalloF, Popolo R, \& Dimaggio G. (2016). Alexithymia, emotion dysregulation, impulsivity and aggression: A multiple mediation model. Psychiatry Research, 237, 296-303.

Whitfield GW. (2016). Validating School Social Work: An Evaluation of a Cognitive-Behavioral Approach to Reduce School Violence. Res Soc Work Pract. 9(4):399-426.

Yoo SH, Matsumoto D, LeRoux JA. (2006). The influence of emotion recognition and emotion regulation on intercultural adjustment. Int $\mathbf{J}$ Intercult Relat 30(3):345-63. 